Article

\title{
Silencing of Transposable Elements Mediated by 5-mC and Compensation of the Heterochromatin Content by Presence of B Chromosomes in Astyanax scabripinnis
}

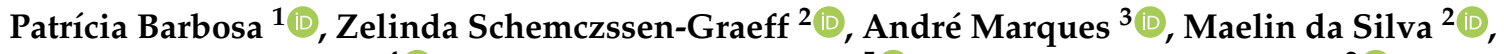 \\ Giovani Marino Favero ${ }^{4}\left(\mathbb{D}\right.$, Bernardo Passos Sobreiro ${ }^{5}\left(\mathbb{D}\right.$, Mara Cristina de Almeida ${ }^{2}{ }^{(0}$,

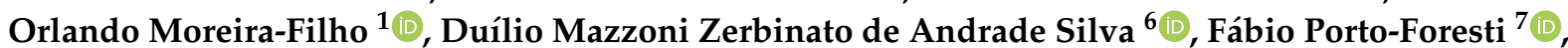 \\ Fausto Foresti ${ }^{6}(\mathbb{D})$ and Roberto Ferreira Artoni ${ }^{1,2, *}$
}

check for updates

\section{Citation: Barbosa, P.;}

Schemczssen-Graeff, Z.; Marques, A.; daSilva, M.; Favero, G.M.; Sobreiro, B.P.; Almeida, M.C.; Moreira-Filho, O.; Silva, D.M.Z.A.; Porto-Foresti, F.; et al. Silencing of Transposable Elements Mediated by 5-mC and Compensation of the Heterochromatin Content by Presence of B Chromosomes in Astyanax scabripinnis. Cells 2021, 10, 1162 https://doi.org/10.3390/cells10051162

Academic Editor: Darren Griffin

Received: 3 April 2021

Accepted: 4 May 2021

Published: 11 May 2021

Publisher's Note: MDPI stays neutral with regard to jurisdictional claims in published maps and institutional affiliations.

Copyright: (c) 2021 by the authors. Licensee MDPI, Basel, Switzerland. This article is an open access article distributed under the terms and conditions of the Creative Commons Attribution (CC BY) license (https:/ / creativecommons.org/licenses/by/ $4.0 /)$.
1 Post Graduate Program in Evolutionary Genetics and Molecular Biology, Department of Genetics and Evolution, Federal University of São Carlos, Rodovia Washington Luís Km 235, São Carlos 13565-905, SP, Brazil; pbarbosa.bio@gmail.com (P.B.); omfilho@ufscar.br (O.M.-F.)

2 Post Graduate Program in Evolutionary Biology, Department of Structural, Molecular and Genetic Biology, State University of Ponta Grossa, Avenida Carlos Cavalcanti 4748, Ponta Grossa 84030-900, PR, Brazil; zelinda1985@hotmail.com (Z.S.-G.); maesilva@uepg.br (M.d.S.); almeidamara@uol.com.br (M.C.d.A.)

3 Department of Botany, Federal University of Pernambuco, Recife 50670-901, PE, Brazil; andre.marques@arapiraca.ufal.br

4 Department of General Biology, State University of Ponta Grossa, Avenida Carlos Cavalcanti 4748, Ponta Grossa 84030-900, PR, Brazil; gmfavero@yahoo.com.br

5 Department of Medicine, State University of Ponta Grossa, Avenida Carlos Cavalcanti 4748, Ponta Grossa 84030-900, PR, Brazil; bsobreiro@hotmail.com

6 Department of Structural and Functional Biology, Institute of Biosciences at Botucatu, Sao Paulo State University (UNESP), Botucatu 18618-689, SP, Brazil; duiliozerbinato@gmail.com (D.M.Z.A.S.); f.foresti@unesp.br (F.F.)

7 Faculty of Sciences, Sao Paulo State University (UNESP), Bauru 01049-010, SP, Brazil; fp.foresti@unesp.br

* Correspondence: rfartoni@gmail.com

Abstract: The way in which transcriptional activity overcomes the physical DNA structure and gene regulation mechanisms involves complex processes that are not yet fully understood. Modifications in the cytosine-guanine sequence of DNA by 5-mC are preferentially located in heterochromatic regions and are related to gene silencing. Herein, we investigate evidence of epigenetic regulation related to the $\mathrm{B}$ chromosome model and transposable elements in A. scabripinnis. Indirect immunofluorescence using anti-5-mC to mark methylated regions was employed along with quantitative ELISA to determine the total genomic DNA methylation level. 5-mC signals were dispersed in the chromosomes of both females and males, with preferential accumulation in the B chromosome. In addition to the heterochromatic methylated regions, our results suggest that methylation is associated with transposable elements (LINE and Tc1-Mariner). Heterochromatin content was measured based on the C-band length in relation to the size of chromosome 1 . The B chromosome in A. scabripinnis comprises heterochromatin located in the pericentromeric region of both arms of this isochromosome. In this context, individuals with B chromosomes should have an increased heterochromatin content when compared to individuals that do not. Although, both heterochromatin content and genome methylation showed no significant differences between sexes or in relation to the occurrence of $B$ chromosomes. Our evidence suggests that the B chromosome can have a compensation effect on the heterochromatin content and that methylation possibly operates to silence TEs in A. scabripinnis. This represents a sui generis compensation and gene activity buffering mechanism.

Keywords: epigenetics; transposable elements; regulation; methylation; isochromosome 


\section{Introduction}

The way in which transcriptional activity overcomes the physical DNA structure and gene regulation mechanisms involves complex processes that are not yet fully understood. Epigenetic marking, characterized by a heritable and reversible change that regulates gene expression without modifying the DNA sequence [1], such as cytosine methylation, histone modifications, and interference RNA [2], is an open area of research for describing this process. One chemical modification that occurs in the DNA dinucleotide cytosine-guanine sequence $(\mathrm{CpG})$ is 5-methylcytosine (5-mC), where CpG methylation occurs on the fifth carbon of the cytosine [1]. Most CpG dinucleotides (75\%) are methylated, corresponding to $1 \%$ of total bases. CpG clusters, also called CpG islands, are gene sequences of open chromatin that promote transcription; hence, the cytosines in these sites are not methylated. DNA is methylated by methyltransferase enzymes [3]. While the methylation location is meaningful in heterochromatic regions [4,5], it is also remarkable in fractions of structural genes [6]. In mammals, DNA methylation marks the silencing of gene regions [7]. In this way, the inactivation of transposable elements (TEs) and repetitive elements can be the result of this epigenetic marking. Examples occur in ribosomal DNA sites (rDNA) of the fish Astyanax janeiroensis [8,9] or plants of the Citrus genus [5]. In this context, transposable elements that initiate their cycle with a small invasion in the genome, followed by an amplification of the number of copies, can lose their motility capacity through mutations (Kidwell and Lish, 2001) or by the action of epigenetic mechanisms [10,11].

DNA methylation is not the only modification responsible for gene regulation in the chromatin condensation level. Eukaryote genomes are packaged in chromatin, represented by the nucleosome and the histone octamer [12]. This packaging occurs during cellular division, altering the chromosomic dynamic [13]. Modifications occurring in the histones affect the chromatin structure directly and consequently affect protein interactions. Such modifications alter the levels of DNA compaction, implying the activation/inactivation of transcriptional genes [14]. They may also aid in the recruitment of chromatin modifiers, such as methyl tags and recognition proteins [12]. The amino acid chains of four histones possess post-translational modification sites (lysine acetylation; mono-, di-, and tri-methylation of lysines; serine phosphorylation, etc.), which have distinct functions of interference in the function and integrity of the genome [15]. DNA methylation and histone methylation act in agreement to maintain the silenced state of the chromatin [13].

$\mathrm{B}$ chromosomes are described in many organisms and defined as extra, expendable elements to the genome [16]. The fish Astyanax scabripinnis has been presented as a good model for studying B chromosomes [17]. Generally, the B chromosomes of A. scabripinnis are partially heterochromatic isochromosomes [18] that suffer auto-paring in meiosis [19] and accumulate families of repetitive DNA, such as As51 satellite DNA [20] and the retrotransposon LINE [21]. Nevertheless, the functional aspects of these chromosomes remain an open question. We aimed to investigate evidence of the epigenetic regulation of B chromosomes in the model species $A$. scabripinnis.

\section{Materials and Methods}

\subsection{Samples and Chromosomic Preparations}

We analyzed 62 specimens ( 28 male and 34 female) of Astyanax aff. scabripinnis from the Campos de Jordao region, Sao Paulo State, Brazil, collected with the permission of the Ministério do Meio Ambiente, Instituto Brasileiro do Meio Ambiente e dos Recursos Naturais Renováveis, Instituto Chico Mendes de Conservação da Biodiversidade-ICMBio MMA/IBAMA/SISBIO, number 15115-1: Stream of Fazenda Lavrinha $\left(22^{\circ} 40^{\prime} 49.5^{\prime \prime} \mathrm{S}\right.$ and $45^{\circ} 23^{\prime} 31.9^{\prime \prime} \mathrm{W}$ ). For cytogenetic analysis, specimens were anesthetized with benzocaine $0.01 \%$ and dissected. The mitotic chromosomes were obtained from kidney tissue according to Bertollo et al. [22]. C-banding was realized following the protocol described by Sumner [23]. The chromosomes were classified as metacentric $(\mathrm{m})$, submetacentric (sm), subtelomeric (st), and acrocentric (a), as proposed by Levan et al. [24], and organized in the decreasing order of the karyotype. All procedures were undertaken according to the 
international animal testing protocol and authorized by the Committee of Ethics in Animal Experimentation (protocol number 4509/08) of the State University of Ponta Grossa. The specimens were identified and received a deposit number for the Collection NUPELIA (Núcleo de Pesquisas em Limnologia, Ictiologia e Aquicultura) of the State University of Maringá (number NUP 17482).

\subsection{Quantification of the Methylation and Heterochromatic Regions}

Genomic DNA was extracted from B+ and B - individuals using the CTAB method [25] and purified (Macherey-Nagel GmbH and Co. KG, Bethlehem, PA, USA) according to the manufacturer's instructions. The total 5-methylcytosine (5-mC) was determined using the 5-mC DNA ELISA kit (Zymo Research Corp., Irvine, CA, USA) according to the manufacturer's instructions. The kit uses an anti-5-methylcytosine monoclonal antibody that is sensitive and specific to $5-\mathrm{mC}$. The result was expressed as a percentage of 5-mC in a DNA sample, calculated using a standard curve generated with specially designed controls included in the kit. This method was used to compare levels of 5-mC between male and female DNA, with the presence and absence of supernumerary chromosomes.

The quantification of heterochromatin (HT) was measured in 32 metaphases, 16 B+ (eight males; eight females) and $16 \mathrm{~B}$ - (eight males; eight females), using ImageJ software (US National Institutes of Health, Bethesda, MD, USA). The length of heterochromatin blocks (LHB) was measured in relation to the total length of the higher chromosome (first pair metacentric) of the complement (LCC), where rate HT = LHB/LCC.

\subsection{Statistical Analysis}

The mean comparison between groups was realized by analysis of variance (ANOVA) using Tukey's post hoc test after normalization of data by logarithmic transformation. The alpha error established for statistical significance was 5\%.

\subsection{Immunodetection of Methylated DNA, Chromosome Probe, and Fluorescence In Situ Hybridization (FISH)}

Immunoassay of 5-methylcytosine (Eurogentec, cat No. MMS-900P-A) was performed according to Ruffini-Castiglione et al. [26]. For sequential hybridization of the As51 satellite DNA sequence, the following protocol for washing and removing the antibody was established: washing and stabilization with PBS $1 \times$ for $10 \mathrm{~min}$, washing in $4 \times$ SSC $/ 0.05 \%$ Tween at room temperature for $10 \mathrm{~min}$, and alcoholic series $70 \%, 80 \%$, and $90 \%$ for $5 \mathrm{~min}$ each.

The satellite DNA As51 described by Mestriner et al. [20] was obtained from the nuclear DNA of $A$. scabripinnis using the primers Fw $5^{\prime}$-GGTCAAAAAGTCGAAAAA- $3^{\prime}$ and Rv $5^{\prime}$-GTACCAATGGTAGACCAA-3' during 35 cycles of amplification in an Eppendorf Mastercycler (Eppendorf Corporate, Hamburg, Germany) $\left(1 \mathrm{~min}\right.$ at $95{ }^{\circ} \mathrm{C}, 45 \mathrm{~s}$ at $56{ }^{\circ} \mathrm{C}$, $1 \mathrm{~min}$ at $72{ }^{\circ} \mathrm{C}$, and $5 \mathrm{~min}$ at $72{ }^{\circ} \mathrm{C}$ ). The element Tc1-Mariner [27] was obtained using the unique primer $5^{\prime}$-CACTCACCGGCCACTTTATTA-3 $3^{\prime}$ during 35 cycles of amplification $\left(1 \mathrm{~min}\right.$ at $94{ }^{\circ} \mathrm{C}, 50 \mathrm{~s}$ at $62.5^{\circ} \mathrm{C}, 2 \mathrm{~min}$ at $72{ }^{\circ} \mathrm{C}$, and $5 \mathrm{~min}$ at $\left.72{ }^{\circ} \mathrm{C}\right)$. The PCR was conducted in a 25 -microliter reaction mix with $0.4 \mu \mathrm{M}$ of primer, $200 \mathrm{ng}$ of DNA template, $0.2 \mathrm{mM}$ of dNTPs, $1 \times$ reaction buffer, $2.0 \mathrm{mM}$ of $\mathrm{MgCl}_{2}$, and $2 \mathrm{U}$ of Taq Polymerase (Invitrogen, Waltham, MA, USA). The element LINE [21] was obtained from the nuclear DNA of $A$. scabripinnis using the primers Fw 5'-CAGTGTGCATCTGATTGTGT-3 ${ }^{\prime}$ and Rv 5'-CGCAGACGCTTTTATCCA-3' during 35 cycles of amplification in the Eppendorf Mastercycler $\left(1 \mathrm{~min}\right.$ at $95{ }^{\circ} \mathrm{C}, 45 \mathrm{~s}$ at $56^{\circ} \mathrm{C}, 1 \mathrm{~min}$ at $72{ }^{\circ} \mathrm{C}$, and $5 \mathrm{~min}$ at $\left.72{ }^{\circ} \mathrm{C}\right)$.

The satellite DNA probe As51 and the elements Tc1-Mariner and LINE were labeled with Nick translation using biotin 14-dATP (Bionick Labeling System, Invitrogen, Waltham, MA USA) and digoxigenin 16-dUTP (Dignick mix, Roche, Mannheim, Germany) in a dry bath (Loccus Biotecnologia, São Paulo, SP, Brazil) (1 h $30 \mathrm{~min}$ at $65^{\circ} \mathrm{C}$ and $15 \mathrm{~min}$ at $\left.15^{\circ} \mathrm{C}\right)$, respectively.

FISH was performed using the protocol of Pinkel et al. [28], adapted for fish in high stringency conditions $(2.5 \mathrm{ng} / \mathrm{mL}$ probe, $50 \%$ deionized formamide, $10 \%$ sulfate dextran, $2 \times \mathrm{SSC}$ at $37^{\circ} \mathrm{C}$ overnight). After hybridization, slides were washed in $15 \%$ 
formamide $/ 0.2 \times \mathrm{SSC}$ at $42{ }^{\circ} \mathrm{C}$ for $20 \mathrm{~min}$ and $4 \times \mathrm{SSC} / 0.05 \%$ Tween at room temperature for $10 \mathrm{~min}$. The As51 probe was detected using Alexa Fluor 488 streptavidin (Molecular Probes ${ }^{\mathrm{TM}}$ ). Anti-digoxigenin-rhodamine (Roche, Mannheim, Germany) was used to detect the Tc1-Mariner element probe. The chromosomes were counterstained with DAPI $(0.2 \mu \mathrm{g} / \mathrm{mL})$ diluted in antifading solution (Fluka, Mannheim, Germany). The metaphases were analyzed using epifluorescence microscopy (Zeiss AxioCam MRm and ZEN Pro 2011 software (version 1.1.0.0, Carl Zeiss, Oberkochen, Germany).

\subsection{Sequencing and Characterization of the Tc1-Mariner Element Obtained Fragment}

The amplification products for the Tc1-Mariner element were separated in 1\% agarose gel, and the DNA bands were purified using a PCR DNA and Gel Band Purification Kit (GE Healthcare, Chicago, IL, USA) according to the manufacturer's instructions. The sequences were linked to the plasmid pGEM ${ }^{\circledR}$-T Easy Vector Systems (Promega, Madison, WI, USA) and transformed into cells of competent Escherichia coli $\mathrm{DH} 5 \alpha$ using $\mathrm{CaCl}_{2}$ treatment. Recombinant plasmids were extracted by mini-preparation using the Illustra plasmidPrep Mini Spin Kit (GE Healthcare). Nucleotide sequencing of the clones and DNA fragments was performed in an automatic sequencer ABI $3130 \times 1$ using the Big Dye kit (Applied Biosystems, Foster City, CA, USA) according to the manufacturer's instructions. The sequences were aligned in the Clustal W program [29], using the BioEdit v7.0 editor [30]. To verify their identity, the sequences were subjected to a search against the database of Dfam (https:/ / dfam.org/search/sequence accessed on 5 May 2021) [31] and then deposited on GenBank (http:/ / www.ncbi.nlm.nih.gov/genbank/ accessed on 5 May 2021) with the following accession number: MT038010.

\section{Results}

A modal diploid number of $2 n=50$ chromosomes was confirmed for $A$. scabripinnis with a polymorphic occurrence of an additional $B$ chromosome.

The 5-mC signals showed that it dispersed in mitotic metaphase chromosomes in both females and males. Additionally, the B chromosome evidenced preferential accumulation of 5-mC (Figure 1a,d). After 5-mC detection, the slides were sequentially submitted to fluorescent in situ hybridization with the As51 satellite DNA probe (Figure 1b,e) and C-banding (Figure 1c,f).

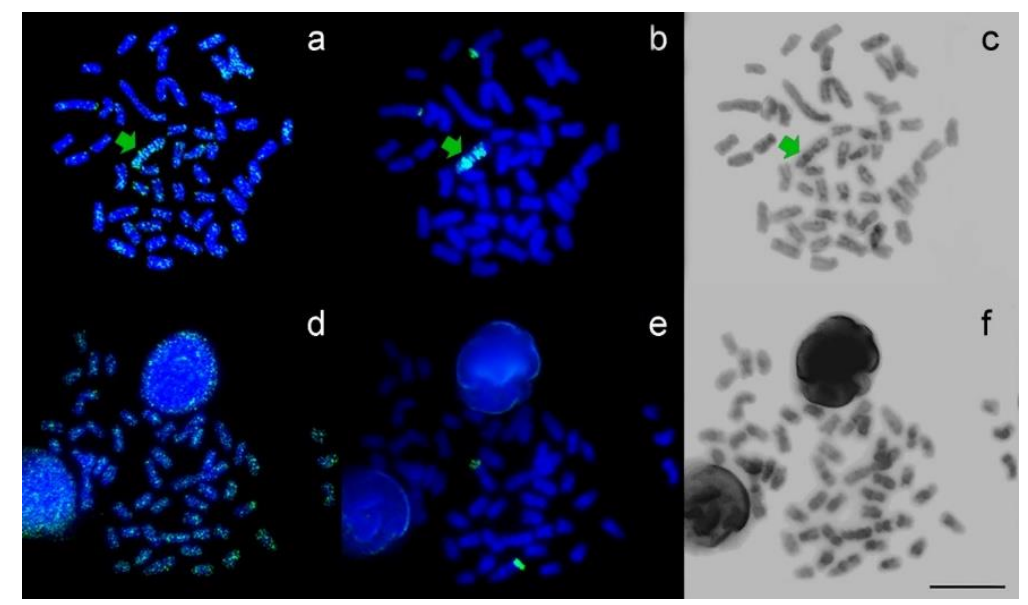

Figure 1. Metaphases of $\mathrm{B}+(\mathbf{a}-\mathbf{c})$ and $\mathrm{B}-(\mathbf{d}-\mathbf{f})$ Astyanax scabripinnis sequentially treated with anti5-mC (a,d), FISH with an As51 probe (b,e), and localization of heterochromatin regions using the $\mathrm{C}$-banding technique $(\mathbf{c}, \mathbf{f})$. The $\mathrm{B}$ chromosome is indicated by green arrow It is possible to observe an evident marking in the telomeric region of another chromosomal pair, both in the $\mathrm{B}+$ and $\mathrm{B}-$ genomes, strongly marked by $A s 51$ probes $(\mathbf{b}, \mathbf{e})$. One of the pairs of complement A is probably related to the origin of the $\mathrm{B}$ chromosome of $A$. scabripinnis. $\mathrm{Bar}=10 \mu \mathrm{m}$. 
The results indicate that both the location of the satellite DNA and the heterochromatic regions are not exclusively associated with methylation regions. The As51 satellite DNA was located in an acrocentric chromosomic pair and a pericentromeric region in both arms of the B chromosome, while the heterochromatic regions were located in pericentromeric regions of most chromosomes and in the distal region of pair one, while the $\mathrm{B}$ chromosome was partially heterochromatic.

FISH revealed a dispersed pattern of localization of the Tc1-Mariner transposable element between the A and B chromosomes, as well as an accumulation in the short arm of metacentric pair 2 and blocks concentrated in the short arm of a medium metacentric pair (Figure 2a). The in situ localization of LINE was scattered in all chromosomes of the standard complement and in the B chromosome, with preferential accumulation along a pair of complement submetacentric chromosomes (Figure 2b).

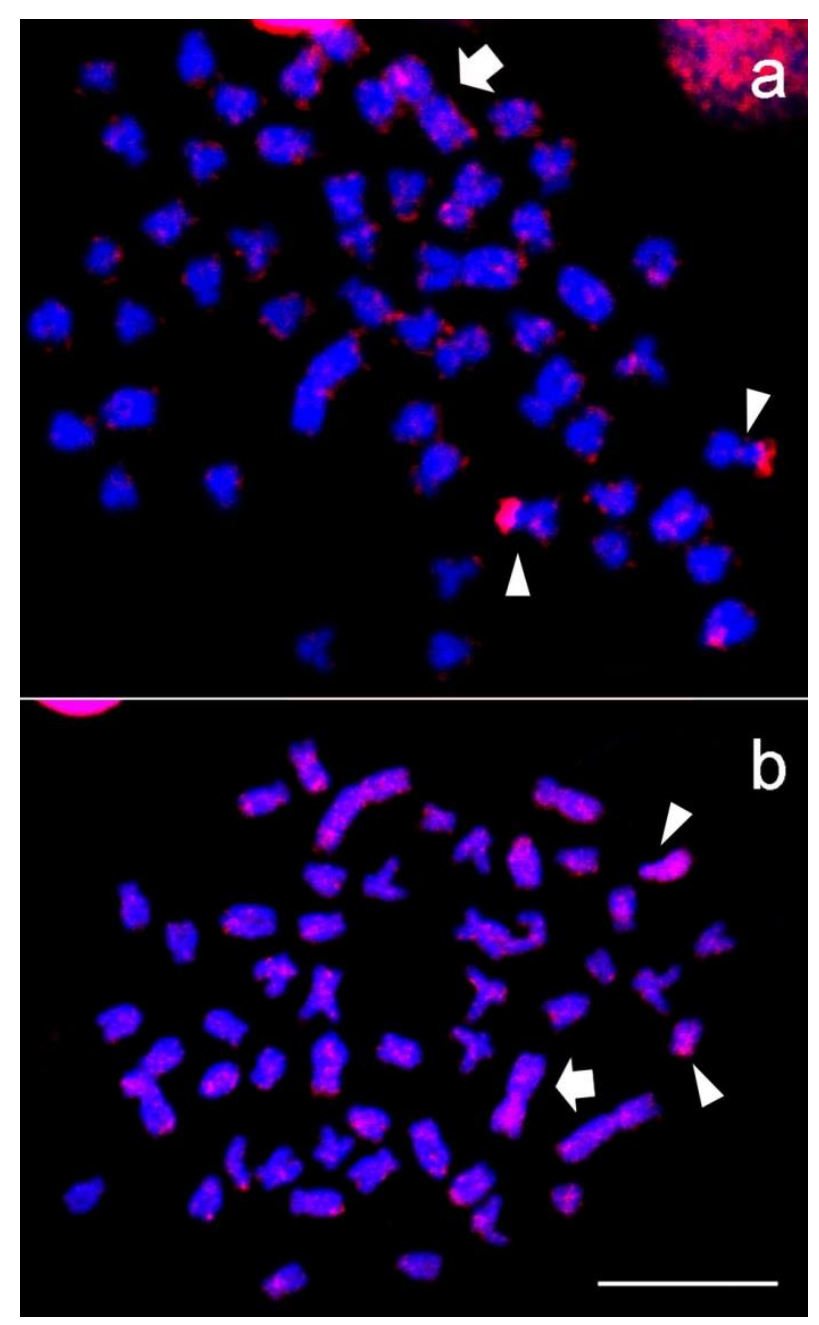

Figure 2. Chromosome mapping with the probes Tc1-Mariner (a) and LINE (b) in Astyanax scabripinnis. B chromosomes are indicated by the big arrows. Tc1-Mariner presents preferential accumulation in the short arm of a medium metacentric pair (little arrow) and small blocks in the other complement chromosomes. LINE has a pattern of localization dispersed in the other chromosomes, with strong accumulation along a pair of complement submetacentric chromosomes (arrows). Bar $=10 \mu \mathrm{m}$.

In contrast with the 5-mC and in situ hybridization, the indirect immunofluorescence of the Tc1-Mariner and LINE probes suggests that the transposable element regions are methylated (Figure 3). 


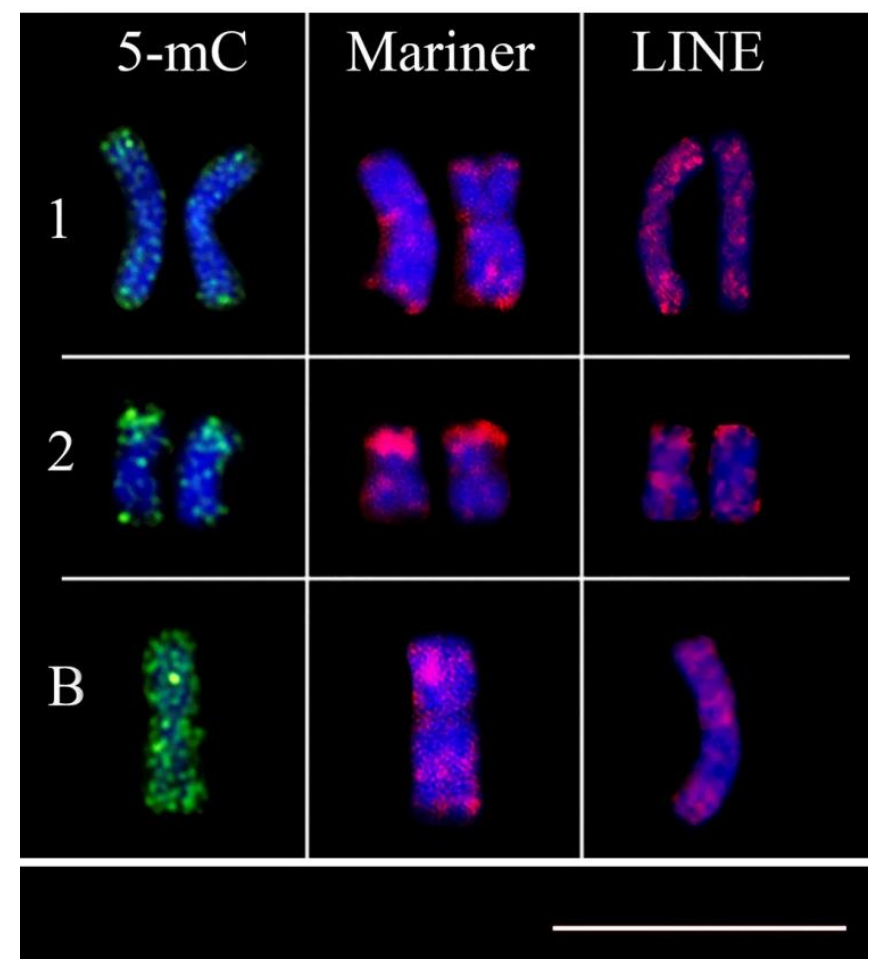

Figure 3. Association of immunodetection of methylated DNA and transposable elements. $\mathrm{n}$ the first line, chromosome pair 1, highlighted in the second line, the metacentric chromosome pair, and finally B chromosome, all marked by $5 \mathrm{mC}$, Tc1-mariner and LINE, respectively Bar $=10 \mu \mathrm{m}$.

A partial sequence of the Tc1-Mariner transposon was obtained from the A. scabripinnis population in the present study. The obtained nucleotide sequence was submitted to the Dfam sequence search (https:/ / dfam.org/family/DF0003847/features accessed on 5 May 2021) and showed about an $87 \%$ similarity with the Tc1-Mariner DNA transposon of the Danio rerio (Figure 4).

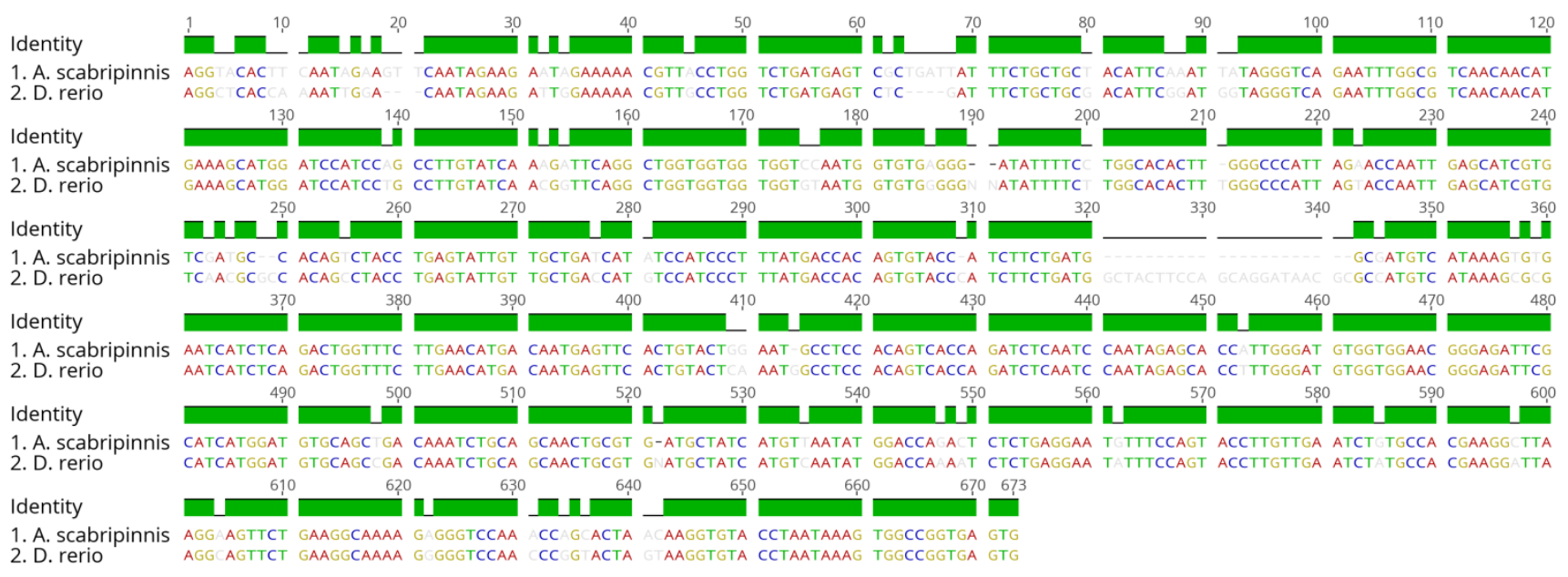

Figure 4. Alignment of the Tc1-Mariner transposon sequences of A. scabripinnis and D. rerio, showing a pairwise identity of 87\%. The alignment was performed using Geneious v10.2.6.

The quantification of 5-mC levels in the genomic DNA and total heterochromatin (TH) was not significantly different between individuals (Tables 1 and 2). Individual data can be found in tables in the Supplementary Materials (Tables S1 and S2). The mean percentage of 5 -mC in male individuals without extra chromosomes was $10.7 \%$, and the mean quantity of 
$\mathrm{TH}$ was 23.9. For individuals carrying the B chromosome, these values were $13.3 \%$ (5-mC) and $25.8(\mathrm{TH})$.

Table 1. Summary of 5-mC levels measured in the genomic DNA of Astyanax scabripinnis. Individuals 1 and 2 are male $\mathrm{B}+$ and $\mathrm{B}-$, respectively. Individuals 3 and 4 are females, $\mathrm{B}+$ and $\mathrm{B}-$, respectively. Confidence interval for mean: $p>95 \%$.

\begin{tabular}{ccccc}
\hline & Number of Cells & Mean & Lower Bound & Upper Bound \\
\hline 1 & 242 & 0.1273 & 0.1055 & 0.1490 \\
2 & 233 & 0.1582 & 0.1316 & 0.1848 \\
3 & 241 & 0.1163 & 0.0975 & 0.1352 \\
4 & 214 & 0.1390 & 0.1137 & 0.1643 \\
Total & 930 & 0.1349 & 0.1233 & 0.1465 \\
\hline
\end{tabular}

Table 2. Summary of heterochromatin (TH) values measured in chromosomes of Astyanax scabripinnis. Individuals 1 and 2 are male $\mathrm{B}+$ and $\mathrm{B}-$, respectively. Individuals 3 and 4 are females, $\mathrm{B}+$ and $\mathrm{B}-$, respectively. Confidence interval for mean: $p>95 \%$.

\begin{tabular}{ccccc}
\hline & Number of Cells & Mean & Lower Bound & Upper Bound \\
\hline 1 & 242 & -1.0056 & -1.0363 & -0.9749 \\
2 & 233 & -0.9478 & -0.9857 & -0.9100 \\
3 & 241 & -1.0385 & -1.0684 & -1.0085 \\
4 & 214 & -1.0084 & -1.0480 & -0.9688 \\
Total & 930 & -1.0003 & -1.0176 & -0.9830 \\
\hline
\end{tabular}

Females without B chromosomes had higher average values than males, with $15.3 \%$ $(5-\mathrm{mC})$ and $22(\mathrm{TH})$. The averages for females with the extra chromosome were $13.9 \%$ (5-mC) and 23.3 (TH). Results for 5-mC and for TH are shown in Figure 5.

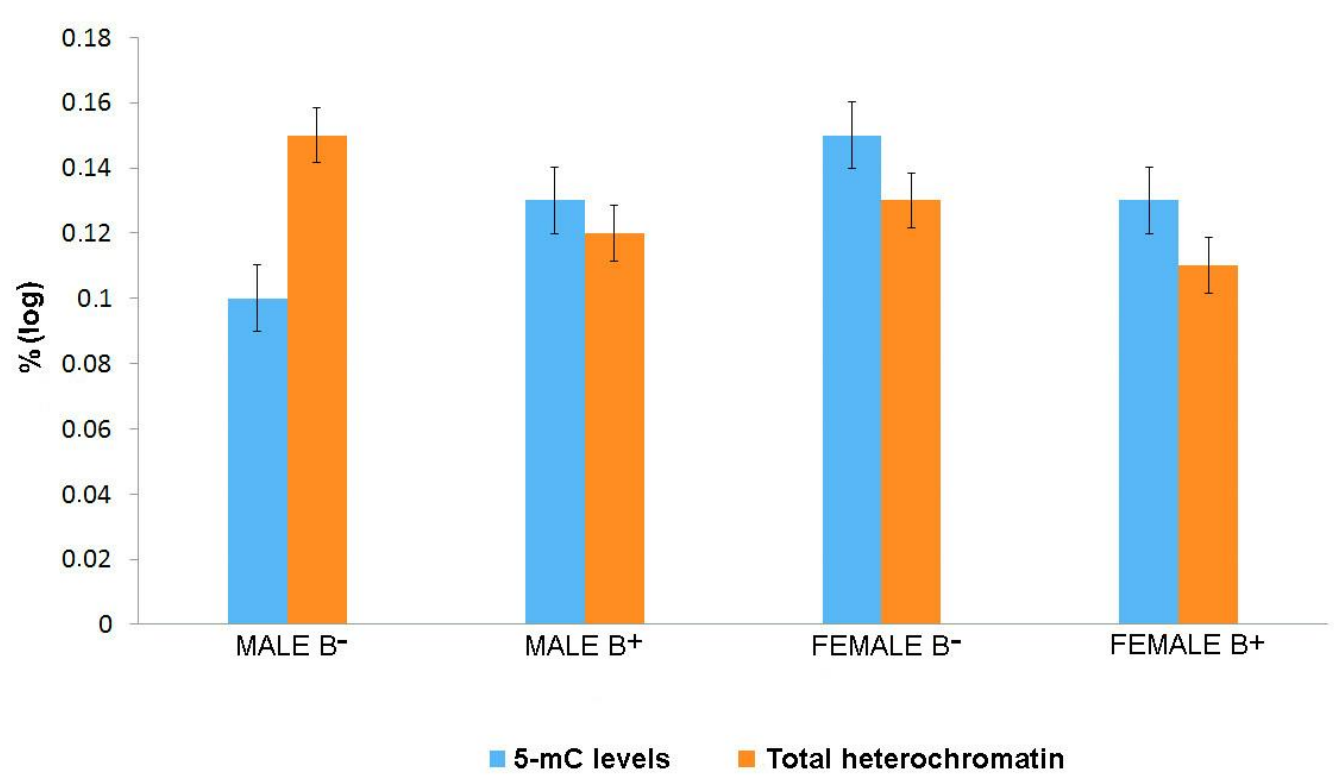

Figure 5. Bar plot showing the methylation conditions of the total genomic DNA (blue) and heterochromatin content (orange). Genome of male and female without B chromosome is represented by $\mathrm{B}^{-}$and genome with $\mathrm{B}$ chromosome by $\mathrm{B}+$. The data were normalized on a logarithmic scale. 


\section{Discussion}

The total heterochromatin content and the DNA methylation levels did not differ between male and female cells, with and without B chromosomes in Astyanax scabripinnis. However, the amount of TE in $\mathrm{B}-$ and $\mathrm{B}+$ genomes shows a difference, since the $\mathrm{B}$ chromosome behaves as a deposit of moving elements. This likely represents a compensation mechanism and TE silencing.

The $\mathrm{B}$ chromosomes of A. scabripinnis were composed of a greater amount of heterochromatin in the pericentromeric region of the short and long arms [18-20] and this study. Thus, individuals with B chromosomes would be expected to have a higher heterochromatin content when compared to individuals without them. However, our results show that the presence of a B chromosome in the karyotype did not alter the heterochromatin quantity found in the genome $(p=0.022)$. We suggest that there is possible compensation for the total content of heterochromatin between B chromosome-carrying individuals and non-carrier individuals; heterochromatin quantity is broadly distributed in the complement A chromosomes when a B chromosome is absent. Our findings are similar to those of Chumová et al. [32], who analyzed the effect of the presence of a B chromosome on the size of the genome of the grass Anthoxanthum. They found that the intraspecific variability of heterochromatin occurring in this genus was caused by complement A chromosomes and not by the presence of $\mathrm{B}$ chromosomes.

Astyanax scabripinnis is characterized by the formation of small and isolated populations, which facilitates the establishment. This leads to polymorphism and karyotype variability between individuals (revisited by Moreira-Filho et al. [17]). In this scenario, different populations tend to present a marked polymorphism of heterochromatin [33]. Polymorphic chromosome patterns of distribution of heterochromatin also occur in other species of Astyanax, including A. fasciatus [34], A. serratus (cited as Astyanax sp. D) [35], and A. bockmanni [36]. Nonetheless, the mechanism that generates this diversification in the chromosomic distribution of heterochromatin remains to be investigated.

Constitutive heterochromatin is recognized as a highly stable structure, is transcriptionally inactive, and is comprised of repetitive elements. Yet, recent studies affirm that these regions are highly dynamic, and their maintenance could be related to the transcription and participation of non-coding RNAs, cell aging, or even stress and epigenetic modifications (revisited by Wang et al. [37]). In Drosophila, the heterochromatin located next to the genes responsible for eye color causes "white-red" variegation, suggesting heterochromatin's ability to regulate nearby genes [38].

Utilizing the specific antibody anti-5-mC against metaphases of A. scabripinnis showed a dispersed methylation profile between the euchromatic and heterochromatic regions. Indirect immunofluorescence followed by C-banding revealed that methylated DNA is not exclusively associated with heterochromatic regions. This differs from the results obtained by Schmid et al. [39], where hypermethylated chromosomal regions in nine species of fish were confined to constitutive heterochromatin, including the sex chromosomes present in these species, as in mammals [40] and birds [41]. In the context of $A$. scabripinnis, these results indicate that the gene silencing mechanism occurs broadly in the genome, not only in the heterochromatic regions. These data suggest strong epigenetic interference in the genome of $A$. scabripinnis.

The levels of 5-mC obtained by ELISA from the total genome of individuals with and without B chromosomes did not show significant differences in methylation $(p=0.02)$, reinforcing the hypothesis that the $\mathrm{B}$ chromosome blocks the gene inactivation in this species when it is present in the genome. DNA methylation patterns were investigated and analyzed through in situ digestion with restriction endonucleases for B chromosomes in the grasshopper Eyprepocnemis plorans during various life stages. In this case, although these cells are not methylated, the NOR regions remain inactive, indicating that methylation is not a direct cause of suppression of ribosomal genes in this species [42]. On the other hand, RNA sequences denominated as piRNA that have 25 to 32 nucleotides participate in silencing TEs through post-transcriptional mechanisms and through epigenetic changes. In 
flies and mice, where the chromatin conformational change mechanism is better understood, the piRISC complex helps to induce methylation patterns in specific loci of DNA from which TEs are expressed [43].

Indirect immunofluorescence and in situ hybridization suggest an association among methylated regions and the localization of the transposable elements LINE and Tc1-Mariner. Transposons and retrotransposons are targets of DNA methylation, a defense of the host genome against proliferation and deleterious consequences of these TEs [44]. However, the methylation of cytosine may not be the only possible cause of silencing [10]. Thus, epigenetic mechanisms are used as a necessary defense to suppress TE activity, making them incapable of producing proteins by silencing chromatin [11]. Although most TEs invade heterochromatic regions [45], physical mapping analyses of LINE [21], and the present study of Tc1-Mariner, demonstrate localization in euchromatic regions, similar to the results obtained by Schemberger et al. [46] in species of Parodontidae. Once TEs scrape off the inactivation and lose their original function, they can suffer a process called "molecular domestication". This tends to benefit the host genome in establishing new cellular functions, such as control of the cellular cycle, proliferation, apoptosis, and chromatin structure (revisited by Sinzelle et al. [47]).

The co-localization of marking (5-mC, LINE, and Tc1-Mariner) in chromosome pairs 1-2 and the $\mathrm{B}$ chromosome of $A$. scabripinnis suggests that these methylated elements are being silenced by the genome. Hypomethylated centromeric regions of the $\mathrm{B}$ chromosome in corn become hypermethylated when transferred into oat plants [48]. In the Citrus species, the methylation of histone $\mathrm{H} 3$ was related to the silencing of retrotransposons, or gene silencing, due to their sparse pattern of accumulation along the euchromatin [5].

We verified a discrete difference in the heterochromatin and DNA methylation content in males and a larger difference in female Astyanax scabripinnis without B chromosomes. Both methodologies indicate a possible sex-linked relationship that should be more deeply explored given the absence of reports of morphologically differentiated sex chromosomes in these fish. The lowest level of methylation was found in males without B chromosomes, in relation to females, despite the heterochromatin content of these males being the highest among all possibilities (Figure 5). This raises the hypothesis that heteromorphism is linked to the male sex in these fish.

In conclusion, this evidence suggests that the $\mathrm{B}$ chromosome of $A$. scabripinnis can exert a compensation effect on the total content of heterochromatin and that methylation acts to silence the transposable elements in this species. This represents a sui generis compensation and gene activity buffering mechanism.

Supplementary Materials: The following are available online at https:/ /www.mdpi.com/article/10 $.3390 /$ cells10051162/s1, Table S1: Individual values of 5- mC in the genomic DNA of B+ and Bmales, Table S2: Individual values of $5-\mathrm{mC}$ in the genomic DNA of B+ and B-females.

Author Contributions: Conceptualization, P.B., M.d.S., O.M.-F. and R.F.A.; methodology, all authors; validation, P.B., Z.S.-G., A.M., G.M.F., B.P.S., M.C.d.A., F.P.-F., F.F. and R.F.A.; formal analysis, P.B., Z.S.-G., A.M., M.d.S., G.M.F., D.M.Z.A.S., F.P.-F., F.F. and B.P.S.; investigation, all authors; writingoriginal draft preparation, P.B., M.d.S., G.M.F. and R.F.A.; writing—review and editing, all authors; supervision, R.F.A. and M.d.S.; project administration, R.F.A.; funding acquisition, M.C.d.A., O.M.-F., G.M.F. and R.F.A. All authors have read and agreed to the published version of the manuscript.

Funding: The author P.B. received a scholarship from the Coordenação de Aperfeiçoamento de Pessoal de Nível Superior (CAPES) (grant Finance Code 001). The author M.d.S. received a scholarship from the Conselho Nacional de Desenvolvimento Científico e Tecnológico (CNPq) (grant 160155/2018-5). The author D.M.Z.A.S. received a scholarship from the Fundação de Amparo à Pesquisa do Estado de São Paulo (FAPESP) (grant 2017/22447-8). This study received financial support from the Conselho Nacional de Desenvolvimento Científico e Tecnológico (CNPq) (grant 407187/2016-2).

Institutional Review Board Statement: Not applicable.

Informed Consent Statement: Not applicable. 
Data Availability Statement: All data are contained within the manuscript, and individual FISH images, tables, and karyotypes are available from the authors on request.

Conflicts of Interest: The authors declare no conflict of interest.

\section{References}

1. Lieb, J.D.; Beck, S.; Bulyk, M.L.; Farnham, P.; Hattori, N.; Henikoff, S.; Liu, X.S.; Okumura, K.; Shiota, K.; Ushijima, T.; et al. Applying whole genome studies of epigenetic regulation to study human disease. Cytogenet. Genome Res. 2006, 114, 1-15. [CrossRef]

2. Vaschetto, L.M. Exploring an emerging issue: Crop epigenetics. Plant Mol. Biol. Report. 2014, 33, 751-755. [CrossRef]

3. Tost, J. DNA methylation: An introduction to the biology and the disease-associated changes of a promising biomarker. Mol. Biotechnol. 2010, 44, 71-81. [CrossRef]

4. Almeida-Toledo, L.F.; Viegas-Péquignot, E.; Coutinho-Barbosa, A.C.; Foresti, F.; Niveleau, A.; de Almeida Toledo-Filho, S. Localization of 5-methylcytosine in metaphase chromosomes of diploid and triploid pacu fish, Piaractus mesopotamicus (Pisces, Characiformes). Cytogenet. Genome Res. 1998, 83, 21-24. [CrossRef]

5. Marques, A.; Fuchs, J.; Ma, L.; Heckmann, S.; Guerra, M.; Houben, A. Characterization of eu-and heterochromatin of Citrus with a focus on the condensation behavior of $45 \mathrm{~S}$ rDNA chromatin. Cytogenet. Genome Res. 2011, 134, 72-82. [CrossRef] [PubMed]

6. Ehrlich, M.; Wang, R.Y. 5-Methylcytosine in eukaryotic DNA. Science 1981, 212, 1350-1357. [CrossRef] [PubMed]

7. Bird, A. Putting the DNA back into DNA methylation. Nat. Genet. 2011, 43, 1050-1051. [CrossRef]

8. Vicari, M.R.; Artoni, R.F.; Moreira-Filho, O.; Bertollo, L.A.C. Colocalization of repetitive DNA and silencing of major rRNA genes. A case report of the fish Astyanax Janeiroensis. Cytogenet. Genome Res. 2008, 122, 67-72. [CrossRef]

9. Barros, A.V.; Sczepanski, T.S.; Cabrero, J.; Camacho, J.P.M.; Vicari, M.R.; Artoni, R.F. Fiber FISH reveals different patterns of highresolution physical mapping for repetitive DNA in fish. Aquaculture 2011, 322, 47-50. [CrossRef]

10. Kidwell, M.G.; Lish, D.R. Perspective: Transposable elements, parasitic DNA, and genome evolution. Int. J. Org. Evol. 2001, 55, 1-24. [CrossRef]

11. Slotkin, R.K.; Martienssen, R. Transposable elements and the epigenetic regulation of the genome. Nat. Rev. Genet. 2007, 8 , 272-285. [CrossRef]

12. Alper, B.J.; Lowe, B.R.; Partridge, J.F. Centromeric heterochromatin assembly in fission yeast-balancing transcription, RNA interference and chromatin modification. Chromosome Res. 2012, 20, 521-534. [CrossRef] [PubMed]

13. Grewal, S.I.; Moazed, D. Heterochromatin and epigenetic control of gene expression. Science 2003, 301, 798-802. [CrossRef]

14. Turner, B.M. Histone acetylation and an epigenetic code. BioEssays 2000, 22, 836-845. [CrossRef]

15. Kouzarides, T. Chromatin modifications and their function. Cell 2007, 128, 693-705. [CrossRef] [PubMed]

16. Jones, R.N.; Rees, H. B Chromosomes; Academic Pr: London, UK, 1982; p. 266. ISBN 0123900603.

17. Moreira-Filho, O.; Galetti, P.M., Jr.; Bertollo, L.A.C. B chromosomes in the fish Astyanax scabripinnis (Characidae, Tetragonopterinae): An overview in natural populations. Cytogenet. Genome Res. 2004, 106, 230-234. [CrossRef] [PubMed]

18. Vicente, V.E.; Moreira-Filho, O.; Camacho, J.P.M. Sex-ratio distortion associated with the presence of a B chromosome in Astyanax scabripinnis (Teleostei, Characidae). Cytogenet. Genome Res. 1996, 74, 70-75. [CrossRef] [PubMed]

19. Vicari, M.R.; Pistune, H.F.M.; Castro, J.P.; Almeida, M.C.; Bertollo, L.A.C.; Moreira-Filho, O.; Camacho, J.P.M.; Artoni, R.F. New insights on the origin of B chromosomes in Astyanax scabripinnis obtained by chromosome painting and FISH. Genetica 2011, 139, 1073-1081. [CrossRef]

20. Mestriner, C.A.; Galetti, P.M., Jr.; Valentini, S.R.; Ruiz, I.R.G.; Abel, L.D.S.; Moreira-Filho, O.; Camacho, J.P.M. Structural and functional evidence that a B chromosome in the characid fish Astyanax scabripinnis is an isochromosome. Heredity 2000, 85, 1-9. [CrossRef]

21. Barbosa, P.; Oliveira, L.A.; Pucci, M.B.; Santos, M.H.; Moreira-Filho, O.; Vicari, M.R.; Nogaroto, V.; Almeida, M.C.; Artoni, R.F. Identification and chromosome mapping of repetitive elements in the Astyanax scabripinnis (Teleostei: Characidae) species complex. Genetica 2015, 143, 55-62. [CrossRef] [PubMed]

22. Bertollo, L.A.C.; Takahashi, C.S.; Moreira-Filho, O. Cytotaxonomic considerations on Hoplias lacerdae (Pisces, Erythrinidae). Braz. J. Genet. 1978, 1, 103-120.

23. Sumner, A.T. A simple technique for demonstrating centromeric heterochromatin. Exp. Cell Res. 1972, 75, 304-306. [CrossRef]

24. Levan, A.; Fredga, K.; Sandberg, A.A. Nomenclature for centromeric position on chromosomes. Heredita 1964, 52, 201-220. [CrossRef]

25. Murray, M.G.; Thompson, W.F. Rapid isolation of high molecular weight plant DNA. Nucleic Acids Res. 1980, 8, 4321-4326. [CrossRef] [PubMed]

26. Ruffini-Castiglione, M.; Cremonini, R.; Frediani, M. DNA methylation patterns on plant chromosomes. Caryologia 2002, 55, 275-282. [CrossRef]

27. Schemberger, M.O.; Nogaroto, V.; Almeida, M.C.; Artoni, R.F.; Valente, G.T.; Martins, C.; Vicari, M.R. Sequence analyses and chromosomal distribution of the Tc1/Mariner element in Parodontidae fish (Teleostei: Characiformes). Gene 2016, 593, 308-314. [CrossRef] [PubMed]

28. Pinkel, D.; Straume, T.; Gray, J. Cytogenetic analysis using quantitative, high sensitivity, fluorescence hybridization. Proc. Natl. Acad. Sci. USA 1986, 83, 2934-2938. [CrossRef] [PubMed] 
29. Thompson, J.D.; Higgins, D.G.; Gibson, T.J. CLUSTAL W: Improving the sensitivity of progressive multiple sequence alignment through sequence weighting, position-specific gap penalties and weight matrix choice. Nucleic Acids Res. 1994, 22, 4673-4680. [CrossRef]

30. Hall, T.A. BioEdit: A user-friendly biological sequence alignment editor and analysis program for Windows 95/98/NT. Nucleic Acids Symp. Ser. 1999, 41, 95-98. [CrossRef]

31. Storer, J.; Hubley, R.; Rosen, J.; Wheeler, T.J.; Smit, A.F. The Dfam community resource of transposable element families, sequence models, and genome annotations. Mob. Dna 2021, 12, 2. [CrossRef]

32. Chumová, Z.; Mandáková, T.; Trávníček, P. Are B-chromosomes responsible for the extraordinary genome size variation in selected Anthoxanthum annuals? Plant Syst. Evol. 2016, 302, 731-738. [CrossRef]

33. Mantovani, M.; Abel, L.D.S.; Mestriner, C.A.; Moreira-Filho, O. Accentuated polymorphism of heterochromatin and nucleolar organizer regions in Astyanax scabripinnis (Pisces, Characidae): Tools for understanding karyotypic evolution. Genetica 2000, 109, 161-168. [CrossRef] [PubMed]

34. Pazza, R.; Kavalco, K.F.; Bertollo, L.A.C. Chromosome polymorphism in Astyanax fasciatus (Teleostei, Characidae). Chromosomal location of a satellite DNA. Cytogenet. Genome Res. 2008, 122, 61-66. [CrossRef] [PubMed]

35. Kantek, D.L.Z.; Vicari, M.R.; Peres, W.A.M.; Cestari, M.M.; Artoni, R.F.; Bertollo, L.A.C.; Moreira-Filho, O. Chromosomal location and distribution of As51 satellite DNA in five species of the genus Astyanax (Teleostei, Characidae, Incertae sedis). J. Fish Biol. 2009, 75, 408-421. [CrossRef] [PubMed]

36. Hashimoto, D.T.; Porto-Foresti, F. Chromosome polymorphism of heterochromatin and nucleolar regions in two populations of the fish Astyanax bockmanni (Teleostei: Characiformes). Neotrop. Ichthyol. 2010, 8, 861-866. [CrossRef]

37. Wang, J.; Jia, S.T.; Jia, S. New Insights into the Regulation of Heterochromatin. Trends Genet. 2016, 32, 284-294. [CrossRef]

38. Lippman, Z.; Martienssen, R. The role of RNA interference in heterochromatic silencing. Nature 2004, 431, 364-370. [CrossRef] [PubMed]

39. Schmidt, M.; Steinlein, C.; Yano, C.F.; Cioffi, M.B. Hypermethylated chromosome regions in nine fish species with heteromorphic sex chromosomes. Cytogenet. Genome Res. 2015, 147, 169-178. [CrossRef]

40. Bernardino, J.; Lombard, M.; Niveleau, A.; Dutrillaux, B. Common methylation characteristics of sex chromosomes in somatic and germ cells from mouse, lemur and human. Chromosome Res. 2000, 8, 513-525. [CrossRef]

41. Schimid, M.; Steinlein, C. The hypermethylated regions in avian chromosomes. Cytogenet. Genome Res. 2017, 151, 216-227. [CrossRef]

42. López-León, M.D.; Cabrero, J.; Camacho, J.P.M. Changes in DNA methylation during development in the B chromosome NOR of the grasshopper Eyprepocnemis plorans. Heredity 1995, 74, 296-302. [CrossRef]

43. Russell, S.J.; LaMarre, J. Transposons and the PIWI pathway: Genome defense in gametes and embryos. Reproduction 2018, 156, 111-124. [CrossRef]

44. Bender, J. DNA methylation and epigenetics. Annu. Rev. Plant Biol. 2004, 55, 41-68. [CrossRef]

45. Dimitri, P.; Junakovic, N.; Arcà, B. Colonization of heterochromatic genes by transposable elements in Drosophila. Mol. Biol. Evol. 2003, 20, 503-512. [CrossRef]

46. Schemberger, M.O.; Oliveira, J.I.N.; Nogaroto, V.; Almeida, M.C.; Artoni, R.F.; Cestari, M.M.; Moreira-Filho, O.; Vicari, M.R. Construction and characterization of a repetitive DNA library in Parodontidae (Actinopterygii: Characiformes): A genomic and evolutionary approach to the degeneration of the $W$ sex chromosome. Zebrafish 2014, 11, 518-527. [CrossRef] [PubMed]

47. Sinzelle, L.; Izsvak, Z.; Ivics, Z. Molecular domestication of transposable elements: From detrimental parasites to useful host genes. Cell. Mol. Life Sci. 2009, 66, 1073-1093. [CrossRef] [PubMed]

48. Koo, D.H.; Han, F.; Birchler, J.A.; Jiang, J. Distinct DNA methylation patterns associated with active and inactive centromeres of the maize B chromosome. Genome Res. 2011, 21, 908-914. [CrossRef] [PubMed] 